\title{
openheart Patients expectations and fulfilment of expectations before and after treatment for suspected coronary artery disease assessed with a newly developed questionnaire in combination with established health-related quality of life questionnaires
}

\author{
Annika Odell, ${ }^{1}$ Angela Bång ${ }^{2}$ Paulin Andréll , ${ }^{3}$ Charlotte Widell, ${ }^{1}$
} Henrik Fryklund, ${ }^{4}$ Anders Kallryd, ${ }^{5}$ Hans Tygesen, ${ }^{6}$ Lars Grip ${ }^{1}$

\begin{abstract}
- Additional material is published online only. To view please visit the journal online (http://dx.doi.org/10.1136/ openhrt-2016-000529).
\end{abstract}

To cite: Odell A, Bång $A$, Andréll $P$, et al. Patients expectations and fulfilment of expectations before and after treatment for suspected coronary artery disease assessed with a newly developed questionnaire in combination with established health-related quality of life questionnaires. Open Heart 2017;4:e000529. doi:10.1136/ openhrt-2016-000529

- Prepublication history and additional material is available. To view please visit the journal (http://dx.doi.org/10.1136/ openhrt-2016-000529).

Received 05 September 2016 Revised 20 December 2016 Accepted 03 January 2017

\section{(a) CrossMark}

For numbered affiliations see end of article.

Correspondence to Dr Annika Odell; annika.odell@ vgregion.se, aodell@live.se

\begin{abstract}
Background Clinical decision-making is often based on evidence of outcome after a specific treatment. Healthcare providers and patients may, however, have different perceptions and expectations of what to achieve from a certain healthcare measure.

Aims To evaluate patients' expectations, perceptions and health related quality of life (HRQoL) before a care process including coronary angiography for suspected coronary artery disease and to evaluate the fulfilment of these expectations in relation to established patient reported outcome measures (PROMs) 6 months later. Furthermore, an aim was to try to define meaningful patient reported experience measures (PREMs) in this population.
\end{abstract}

Methods 544 patients planned for coronary angiography completed a newly developed questionnaire to assess expectations and perceptions of treatment, the expectation questionnaire (ExpQ) and two established HRQoL questionnaires together with the established generic Short-Form 36 (SF36) and the disease specific Seattle Angina Questionnaire (SAQ). Results Patients had before the intervention, in general, high expectations of improvement after investigation and treatment and there was a positive attitude towards life style changes, medication and participation in decision-making regarding their own treatment. Only, $56.4 \%$ of the patients, however, reported fulfilment of treatment expectations. Fulfilment of treatment expectations correlated strongly with improvement in HRQoL after the care process.

Conclusions To measure patients' expectations and fulfilments of these may offer simple and meaningful outcomes to evaluate a healthcare process from a patient's perspective. To approach patients' expectations may also strengthen patient involvement in the care process with the possibilities of both higher patient satisfaction and medical results of the treatment.

\section{KEY QUESTIONS}

What is already known about this subject?

- Most studies report endpoints such as death, myocardial infarction and hospitalisations. However, less is known about patients expectations and fulfilment of these after an intervention.

What does this study add?

- Validated methods to measure health related quality of life (HRQLL) already exists, but there are no established instruments to explore the patients' expectations and fulfilment of these after an interventional procedure. This study reports both patient reported outcome and experience measures (patient reported outcome measure (PROMs) and patient reported experience measures (PREMs)) within the same questionnaire (the expectation questionnaire, ExpQ). The ExpQ is found to correlate with known validated HRQOL instruments.

How might this impact on clinical practice?

- Fulfilments of expectations are associated with improvement in quality of life. To measure PROMs and PREMs may be a simple and meaningful measure to evaluate and improve a healthcare process from the patient's perspective.

\section{INTRODUCTION}

For stable symptomatic coronary artery disease $(\mathrm{CAD})$ there are several treatment options for relief of symptoms and to improve long term outcome. These options include lifestyle changes focusing on smoking cessation, physical activity, dietary changes, pharmacological antianginal and antiplatelet therapies as well 
as treatment for hypertension and hyperlipidemia and finally revascularisation measures, especially in patients with widespread and severe CAD. ${ }^{12}$

In a situation with multiple treatment options and constraints on healthcare resources, it is important to use facilities and resources in a cost effective way in order to create the highest possible value for the money spent. ${ }^{3}$ In medical decision-making, therapeutic safety and efficacy are crucial but both have to be defined in terms of meaningful and adequate outcomes. In recent years, there has been a focus on patient perspective and involvement in the decision-making and care processes, in order to both improve resource utilisation and the quality of care. ${ }^{4}$ Thus, from this perspective, patient-reported outcome and experience measures (PROMs and PREMs, respectively) are being increasingly advocated and used to evaluate care processes. ${ }^{5}$

An appraisal from the University of Oxford, including a review of the available PROMs, resulted in the recommendation of just a few that were found to be evidence-based and suitable for the evaluation of care processes in CAD; that is, EuroQol 5-dimensions (EQ-5D), the ShortForm-36 (SF-36) and the Seattle Angina Questionnaire (SAQ). ${ }^{6}$ Although these health-related quality of life (HRQoL) instruments have been used in many cardiovascular studies, little consideration has been taken in incorporating their findings into the development of treatment strategies.

Regarding PREMs, fewer questionnaires have been developed and used in studies or clinical development. ${ }^{7}$ To involve patients, not only the outcomes at the end of the care process should be accounted for, but also the patients' own views and expectations at the beginning of it as well as the extent to which these are subsequently fulfilled. The aims of the present study were to evaluate, at the beginning of a care process including coronary angiography for the evaluation of suspect stable CAD, patient views on different treatment options and expectations regarding the outcome of this process and, furthermore, to evaluate the fulfilment of these expectations in relation to established PROMs for CAD after the care process.

\section{METHODS}

This study was a prospective longitudinal observation study recruiting patients who were referred and planned for an elective coronary angiography for suspected stable $\mathrm{CAD}$ at all the centres performing the procedure in the region Västra Götaland, Sweden. The study started with 15 pilots patients from March to April 2011. Inclusion at the principal centre started in May 2011 (257 patients included) and at three other smaller centres from September to October 2011 (103 95 and 89 patients included, respectively). Inclusion was completed in June 2012. The study was not open for inclusion during vacation periods (in Sweden, middle of June to end of August and during middle of December to middle of January).
During the study periods, all consecutive patients admitted for elective coronary angiography for suspected $\mathrm{CAD}$ were screened for inclusion (figure 1). Patients under the 18 years of age or with insufficient knowledge of the Swedish language were excluded.

The study was approved by the Regional Ethical Review Board at Gothenburg University (DNR: 667-10) and was performed in accordance with the Declaration of Helsinki. Written informed consent was obtained from all patients prior to inclusion. The study was registered at www.clinicaltrials.gov (reg. no.NCT01551927).

Baseline data were collected from the medical records at the time of the coronary angiography. The data from the coronary angiography and clinical outcome were collected at the time of the follow-up visit from the patients and from their medical records.

The established HRQoL questionnaires SF-36 and SAQ were used in the study together with the Expectations Questionnaire (ExpQ), which was developed for the current study.

The baseline questionnaires were given in paper to the patients approximately a week before the angiography or on the ward the same day as the angiography, depending on how the care process for elective coronary angiography was organised at each centre. If the patients did not understand the questions, they could ask the research study nurse at each centre for guidance.

If the follow-up took place at the outpatient clinic, the research nurse gave the follow-up questionnaires to the patients to fill in during the follow-up visit. If the follow-up was done by phone, the follow-up questionnaires were sent by post. If the patients did not respond, the study nurse called twice by telephone. If there still was no response from the patient, the questionnaires were again sent out to the patient with a prepaid return envelope. The research nurses collected the questionnaires.

The SF-36 is a generic questionnaire to assess health status consisting of 36 questions, grouped into eight subscales; physical function, social function, role limitation due to emotional problems, mental health, energy/ vitality, bodily pain and general health. ${ }^{8}$ A score from 0-100 can be obtained on each subscale and a higher score indicates higher HRQoL.

The SAQ is a disease-specific HRQoL questionnaire to assess the functional status of patients with angina pectoris. ${ }^{9}$ The form consists of 19 items divided into five dimensions; physical limitations, angina stability, angina frequency, satisfaction of treatment and disease perception. The results are scored from $0-100$ and a higher score indicates higher HRQoL.

The ExpQ is a questionnaire that was developed for this study to assess patient expectations and perceptions before and after the care process including coronary angiography and any subsequent treatment in individuals with suspected CAD. There are questions regarding patients' perceptions as to why an angiography should be performed, what they think the results will show and their attitudes towards various treatment options. Some 


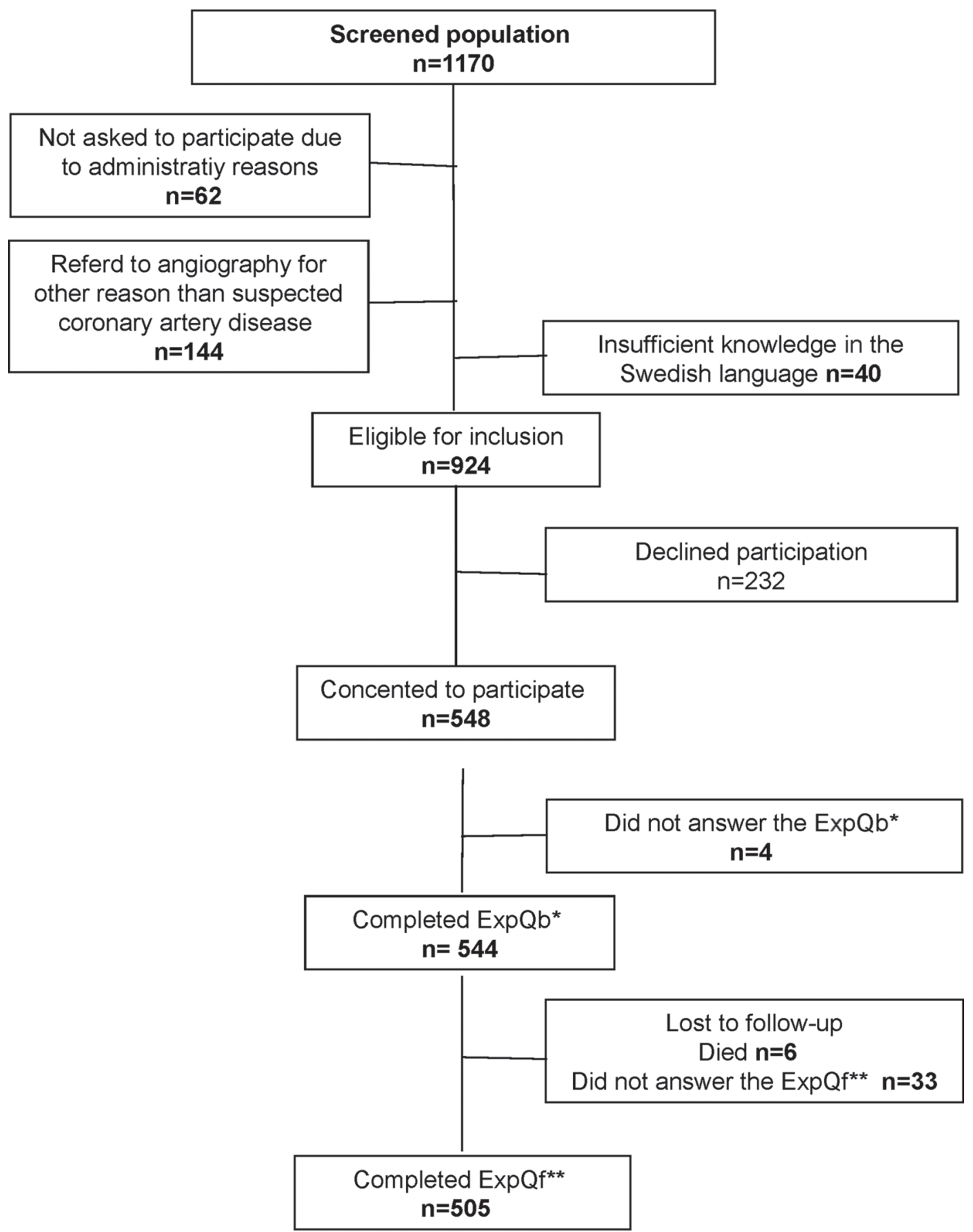

${ }^{\star} \operatorname{ExpQb}=$ Expectation Questionnaire baseline

${ }^{* *}$ ExpQf = Expectation Questionnaire follow up

Figure 1 Screening process of patients for suspected coronory artery disease (CAD). ExpQf, the expectation questionnaire follow-up; ExpQb, the expectation questionnaire baseline.

of the questions are answered with 'single answer alternatives', others with answers ordered on a 4-point Likert scale (agree entirely, agree almost entirely, agree partially and completely disagree) The ExpQ follow-up (ExpQf) follows-up the questions from the ExpQbaseline (ExpQb) to examine how the patient's expectations have been met after the care process. The ExpQb consists of 11 questions while the ExpQf consists of seven questions. The results are given in numbers and percentages and are not calculated with points or scores. The ExpQ questionnaires were produced only in Swedish (which was why sufficient knowledge in Swedish was a prerequisite for participation in the study). The Swedish originals are included in the online supplementary material (online supplementary 
Table 1 Clinical characteristics at baseline and results at follow-up regarding number of coronary angiographies and interventions as well as occurrence of angina pectoris and heart failure

\begin{tabular}{|c|c|}
\hline Baseline & $n=544$ \\
\hline \multirow[t]{2}{*}{ Age, mean, SD in years } & $65.0(9.9)$ \\
\hline & n \% \\
\hline Women & $147(27.0)$ \\
\hline Men & $397(73.0)$ \\
\hline Angina pectoris & $405(74.4)$ \\
\hline Previous myocardial infarction & $140(25.7)$ \\
\hline Heart failure & $62(11.4)$ \\
\hline Systemic hypertension & $308(56.6)$ \\
\hline Hyperlipidaemia & $248(45.6)$ \\
\hline Diabetes mellitus & $124(22.8)$ \\
\hline Previous stroke or TIA & $40(7.4)$ \\
\hline Chronic obstructive pulmonary disease & $24(4.4)$ \\
\hline Previous PCl & $164(30.1)$ \\
\hline Previous CABG & $76(14.0)$ \\
\hline Current smoker & $47(8.6)$ \\
\hline \multicolumn{2}{|l|}{ Ejection fraction (\%) } \\
\hline $0 \%-49 \%$ & $66(12.1)$ \\
\hline $50 \%-100 \%$ & $448(82.4)$ \\
\hline Patient who did not undergo coronary angiography & $29(5.3)$ \\
\hline Angiography with no significant stenosis & $167(30.7)$ \\
\hline \multicolumn{2}{|l|}{$\begin{array}{l}\text { Interventions, signs and symptom at follow- } \\
\text { up }\end{array}$} \\
\hline $\mathrm{PCl}$ & $187(34.4)$ \\
\hline CABG & $72(13.2)$ \\
\hline $\mathrm{PCl}$ and $\mathrm{CABG}$ & $3(0.6)$ \\
\hline Heart valve surgery/TAVI & $5(0.9)$ \\
\hline CABG and Heart valve surgery & $7(1.3)$ \\
\hline Dead & $6(1.1$ \\
\hline Number of patients who not answered at the ExpQf & $34(6.3)$ \\
\hline Angina symptoms & $124(22.8)$ \\
\hline Heart failure & $41(7.5)$ \\
\hline
\end{tabular}

CABG, coronary artery bypass surgery; ExpQf, expectation questionnaire follow-up, $\mathrm{PCl}$, percutaneous coronary intervention, $\mathrm{TAVI}$, transcatheter aortic valve implantation, TIA, transitory ischemic attack.

appendices I and II) as well as their English translations (online supplementary appendices III and IV).

The ExpQ questionnaires were evaluated in two steps. First, experts on the topic reviewed the questionnaires and, second, a pilot study including 15 patients was performed. In the pilot study the patients also completed a questionnaire regarding user friendliness and understandability and there was a test-retest in which the patients completed the questionnaires twice 1 week apart and comparisons were made by calculating percentage agreements and Kappa values ( $\kappa$ ) (online supplementary appendix V).

\section{STATISTICAL METHODS}

Continuous variables are presented as means and SD. Categorical variables are presented with numbers and percentages.

The answers on the test-retest of the ExpQb and ExpQf were compared with and evaluated if they were consistent regarding percentage agreements. To account for random outcomes in the two tests, an agreement measurement by calculation of the kappa $(\kappa)$ of each question was performed. The $\kappa$ is an agreement measure that is adjusted for an expected random distribution of answers where the value one represents absolute agreement and zero a distribution that does not differ from random distribution.

Each baseline predictors was correlated with the fulfilment of expectations regarding treatment defined as the answer 'I agree entirely' to the question 'The expectations I had regarding my treatment have been met' on the ExpQf, using univarible logistic regression model. The results are presented as an OR with 95\% CI. Univariable significant predictors were entered in to a stepwise logistic regression to find independent predictors.

Spearman's rank correlation coefficient $\left(r_{s}\right)$ was used to compare the results of HRQoL in relation to the four different answer alternatives in the 4-graded Likert scale in the expectations fulfilment question above. For comparison of changes in continuous variables within groups, Wilcoxon signed-rank test was used.

All tests were two-sided and $p$ values below 0.05 were considered statistically significant. Calculations were performed using the Statistical Package for Social Sciences (V.21.0, SPSS, Chicago, Illinois, USA).

\section{RESULTS}

Out of 1170 screened patients, 548 were eligible. Of these, 544 filled in the baseline questionnaires and 505 completed the follow-up and filled in the follow-up questionnaires (figure 1). Baseline characteristics of the patients are shown in table 1 .

At baseline, most patients understood that the purpose of the coronary angiography was to find out whether there were narrowings that imposed a risk or could explain their symptoms. Furthermore, a majority of the patients expected that the angiography would demonstrate narrowings that could be treated appropriately with balloon angioplasty. Only very few expected that the angiography would demonstrate changes for which bypass surgery would be a suitable treatment (table 2).

Most patients wanted to participate in the decision-making process regarding their treatment but $30.7 \%$ of the patients wanted the cardiologist to decide about treatment (table 3).

When asked about preferred treatment, $74.7 \%$ answered that they would prefer balloon angioplasty. There was in general a positive attitude towards life style changes and medical treatment. 
Table 2 Patients' perceptions of the reasons for undergoing coronary angiography and their expectations at follow-up

\section{ExpQb:}

$n=544$

1 a-e. What is, in your opinion, the main reason for you to undergo a coronary angiography?

1a. To investigate whether there are changes in my heart that could pose a risk for my future life.

n $\%$

1b. To investigate what is causing my symptoms.

1c. To investigate whether any intervention can be performed to make my symptoms disappear.

$1 d$. To investigate whether my heart is healthy enough for me to undergo other planned surgery (not on the heart).

$184 \quad 33.8$

1e. I will be investigated prior to undergoing heart valve surgery.

$18 \quad 3.3$

\section{3a-f. What do you expect the coronary angiography will show?}

$3 a$. That there is no narrowing of the coronary vessels.

$7 \quad 1.3$

$3 b$. That there is narrowing of the coronary vessels, but not worse than lifestyle changes will suffice as treatment.

$82 \quad 15.1$

$3 c$. That there is narrowing of the coronary vessels, that may explain my symptoms and that the appropriate treatment will be with drugs.

$3 \mathrm{~d}$. That there is narrowing of the coronary vessels that can be appropriately treated with balloon angioplasty.

$57 \quad 10.5$

$3 e$. That there is narrowing of the coronary vessels that is suitable for treatment with bypass surgery.

$86 \quad 15.8$

$3 f$. That there is narrowing of the coronary vessels that cannot be treated with any of the above options.

$11 \quad 2.0$

$5 \quad 0.9$

ExpQb, expectation questionnaire at baseline.

When the patients were asked to rank what was most important to them, the two alternatives that were chosen by a majority, both at baseline and follow-up, were that they 'wanted to be completely free of symptoms' (41.7\% and $39.5 \%$ at baseline and follow-up, respectively) and 'to live a normal life' $(38.8 \%$ and $46.1 \%$ at baseline and

Table 3 Patients' attitudes towards participation in the decision-making process, treatment options, the view on changing their lifestyle and attitudes towards medical therapy at baseline (in questions $5 a-c, 6 a-d, 7 a-d$ and $8 a-c$ in the expectation baseline questionnaire (ExpQb))

ExpQb: $n=544$

\section{5a-c. If coronary angiography shows narrowing of your coronary vessels- What best describes your} attitude towards the choice of treatment?

5a. I have a fixed opinion about which treatment I prefer.

$20 \quad 3.7$

5b. I want to be informed about the treatment options available and then decide together with the responsible cardiologist which $355 \quad 65.3$ treatment I will receive.

$5 c$. I want the responsible cardiologist to decide which treatment I will receive.

$167 \quad 30.7$

\section{6 a-d. Which of the following treatment options would you then prefer?}

\begin{tabular}{lll}
\hline 6a. I would prefer lifestyle changes. & 69 \\
\hline 6b. I would prefer only medical treatment. & 12.7 & 9.0 \\
\hline 6c. I would prefer balloon angioplasty. & 407 \\
\hline 6d. I would prefer bypass surgery. & 74.8 \\
\hline 7 a-d. What is your view on changing your lifestyle? & 2.0 \\
\hline 7a.I would start with lifestyle changes and resort to another treatment later if it becomes necessary. & 155 \\
\hline 7b. I would prefer lifestyle changes only as a complement to other treatment. & 28.5 \\
\hline 7c. I do not want to make any lifestyle changes. & 34.9 \\
\hline 7d. I have already done everything possible in terms of lifestyle changes. & 5.0 \\
\hline
\end{tabular}

\section{$8 \mathrm{a}-\mathrm{c}$. What is your view on a lifelong medical treatment consisting of antithrombotic, lipid-lowering and} cardio-protective drugs?

\begin{tabular}{lll}
\hline 8a. I do not want any medical treatment. & 5.1 & 28 \\
\hline 8b. I can imagine being treated with drugs for a limited time (treatment duration of about 1 year). & 159 & 29.2 \\
\hline 8c. I can imagine lifelong medical treatment. & 344 & 63.2 \\
\hline
\end{tabular}

ExpQb, expectation questionnaire at baseline. 
follow-up, respectively) (online supplementary appendix VI).

At baseline, a majority of the patients trusted that they would receive the necessary information and the treatment that their condition required in a timely manner. In addition, most thought at baseline that they would be well received by the medical staff and be able to feel safe in connection with the care process (figure 2). At follow-up, however, only $56.4 \%$ agreed fully to have had their expectations regarding treatment fulfilled.

In the univariate regression analysis, diabetes and previous coronary bypass grafting (CABG at baseline were found to be associated with a significantly lower fulfilment of treatment expectations (online supplementary appendix VII). When entered into a stepwise logistic regression analysis, only previous CABG remained

\section{Expectations}

\begin{tabular}{|c|c|c|}
\hline 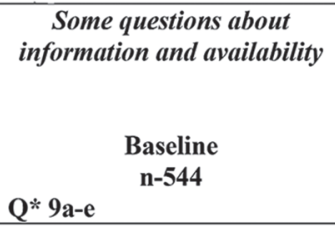 & $\begin{array}{c}\text { How have the expectations } \\
\text { you had regarding } \\
\text { examination, health care and } \\
\text { treatment been met? } \\
\text { Follow-up } \\
\text { n-505 } \\
\begin{array}{l}\mathrm{Q}^{* *} 2 \mathrm{a}-\mathrm{e} \\
\end{array}\end{array}$ & $\begin{array}{l}\begin{array}{l}\text { How do you feel now, six } \\
\text { months after your coronary } \\
\text { angiography? }\end{array} \\
\qquad \begin{array}{c}\text { Follow-up } \\
\text { n-505 }\end{array} \\
\begin{array}{l}Q^{* *} \text { 3a-d } \\
\end{array}\end{array}$ \\
\hline $\begin{array}{l}\text { I trust that I will receive all } \\
\text { necessary information before } \\
\text { any future treatment. }\end{array}$ & $\begin{array}{l}\text { The expectations I had } \\
\text { regarding information before } \\
\text { the examination and treatment } \\
\text { have been met. }\end{array}$ & I feel well informed. \\
\hline $\begin{array}{l}\text { I trust that I will receive the } \\
\text { treatment that my condition } \\
\text { requires. }\end{array}$ & $\begin{array}{l}\text { The expectations I had } \\
\text { regarding my treatment have } \\
\text { been met. }\end{array}$ & \\
\hline $\begin{array}{l}\text { I trust that I will receive the } \\
\text { treatment that I need in a } \\
\text { timely manner. }\end{array}$ & $\begin{array}{l}\text { I have received treatment in a } \\
\text { timely manner. }\end{array}$ & $\begin{array}{l}\square \text { Agree entirely } \\
\square \text { Agree almost entirely } \\
\square \text { Agree partially } \\
\text { Completely clisagree }\end{array}$ \\
\hline $\begin{array}{l}\text { I trust that I will be well } \\
\text { received (by medical staff) in } \\
\text { connection with the } \\
\text { examination, health care, and } \\
\text { treatment. }\end{array}$ & $\begin{array}{l}\text { The expectations I had } \\
\text { regarding the way I would be } \\
\text { received (by medical staff) } \\
\text { have been met. }\end{array}$ & $\begin{array}{l}\text { I feel I have been well taken } \\
\text { care of. }\end{array}$ \\
\hline $\begin{array}{l}\text { I trust that I will be able to feel } \\
\text { safe in connection with the } \\
\text { examination, health care and } \\
\text { treatment that I receive. }\end{array}$ & $\begin{array}{l}\text { The expectations I had } \\
\text { regarding feeling safe have } \\
\text { been fulfilled. }\end{array}$ & I feel safe. \\
\hline & & $\begin{array}{l}\text { I feel I know where to turn if I } \\
\text { should deteriorate. }\end{array}$ \\
\hline
\end{tabular}

Figure 2 Expectations based on expectation questionnaire (ExpQ). 
Table 4 Patients' expectations and outcome regarding recovery at baseline and at follow-up

\begin{tabular}{|c|c|c|c|c|c|}
\hline \multirow[t]{2}{*}{ Baseline } & \multicolumn{2}{|c|}{$\mathrm{n}=544$} & \multirow[t]{2}{*}{ Follow-up } & \multicolumn{2}{|c|}{$\mathrm{n}=505$} \\
\hline & $\mathbf{n}$ & $\%$ & & $\mathbf{n}$ & $\%$ \\
\hline $\begin{array}{l}10 \text { a-d. Do you think that your present state will be affected } \\
\text { by the treatment you will possibly receive after coronary } \\
\text { angiography? }\end{array}$ & & & $\begin{array}{l}5 \text { a-d. How are you feeling } \\
\text { today compared with how you } \\
\text { felt } 6 \text { months ago? }\end{array}$ & & \\
\hline 10a. I expect to be completely recovered / I hope to be completely fine. & 306 & 56.3 & 5a. I am fully recovered. & 102 & 20.2 \\
\hline $\begin{array}{l}\text { 10b. I expect to be almost fully recovered / I hope to improve even if I am not } \\
\text { entirely fine. }\end{array}$ & 203 & 37.3 & 5b. I am almost completely recovered. & 164 & 32.5 \\
\hline 10c. I expect to be only partially recovered / I hope to get somewhat better. & 28 & 5.1 & 5c. I am partially recovered. & 115 & 22.7 \\
\hline 10d. I expect no improvement at all / I have no hopes of getting better. & 1 & 0.2 & sd. I am not at all recovered. & 96 & 19.0 \\
\hline
\end{tabular}

associated with lower fulfilment of treatment expectations.

At baseline, $93.6 \%$ of the patients expected that they would experience complete, or almost complete, recovery of symptoms (table 4$)$.

At follow-up, however, only $52.7 \%$ of the patients reported that they were fully or almost completely recovered and $19 \%$ reported that they were not recovered at all.
Reliability tests revealed that most of the questions regarding expectations were found to be adequate. Furthermore, although the patients on whom the ExpQ were tested and retested were few, percentage agreements were $71.4 \%-100 \%$ and Kappa values were $>0.60$, indicating good or very good agreement, for 12 out of 16 questions regarding expectations (online supplementary appendix V).

Table 5 Health related quality of life (HRQLL) evaluated by Seattle Angina Questionnaire (SAQ) at baseline and follow-up in patients grouped according to their answer to the statement at follow-up that 'The expectations I had regarding my treatment have been met'

\begin{tabular}{|c|c|c|c|c|c|c|c|}
\hline & & $\begin{array}{l}\text { Completely } \\
\text { disagree } \\
\text { Baseline } \\
\mathrm{n}=48 \\
\text { Follow-up } \\
\mathrm{n}=44\end{array}$ & $\begin{array}{l}\text { Agree partially } \\
\text { Baseline } \\
\mathrm{n}==79 \\
\text { Follow-up } \\
\mathrm{n}=76\end{array}$ & $\begin{array}{l}\text { Agree almost } \\
\text { entirely } \\
\text { Baseline } \\
\mathrm{n}=83 \\
\text { Follow-up } \\
\mathrm{n}=81\end{array}$ & $\begin{array}{l}\text { Agree entirely } \\
\text { Baseline } \\
\mathrm{n}=272 \\
\text { Follow-up } \\
\mathrm{n}=264\end{array}$ & $\begin{array}{l}\text { between } \\
\text { the four } \\
\text { alternatives } \\
\text { from } \\
\text { completely } \\
\text { disagree to } \\
\text { agree entirely }\end{array}$ & $\begin{array}{l}\text { from baseline } \\
\text { to follow-up } \\
\text { between the } \\
\text { four alternatives } \\
\text { from completely } \\
\text { disagree to agree } \\
\text { entirely }^{\dagger}\end{array}$ \\
\hline & & Mean (SD) & Mean (SD) & Mean (SD) & Mean (SD) & $\begin{array}{l}r_{s} \\
p \text { value }\end{array}$ & $\begin{array}{l}r_{s} \\
p \text { value }\end{array}$ \\
\hline $\begin{array}{l}\text { Physical } \\
\text { limitation }\end{array}$ & $\begin{array}{l}\text { Baseline } \\
\text { Follow-up } \\
\text { Change }\end{array}$ & $\begin{array}{c}57.1(21.5) \\
55.6(21.1) \\
-0.945(13.943)\end{array}$ & $\begin{array}{c}55.7(17.0) \\
60.6(20.9) \\
4.18(15.6)^{\star}\end{array}$ & $\begin{array}{c}66.01(19.9) \\
74.8(20.2) \\
8.25(16.8)^{\star \star \star}\end{array}$ & $\begin{array}{c}65.6(19.1) \\
79.5(19.0) \\
13.5(19.2)^{\star \star \star}\end{array}$ & $\begin{array}{c}r_{s}=0.18 \\
0.0001 \\
r_{s}=0.38 p<0.0001\end{array}$ & $\begin{array}{l}r_{s}=0.26 \\
<0.0001\end{array}$ \\
\hline $\begin{array}{l}\text { Angina } \\
\text { stability }\end{array}$ & $\begin{array}{l}\text { Baseline } \\
\text { Follow-up } \\
\text { Change }\end{array}$ & $\begin{array}{l}41.8(21.1) \\
43.5(21.4) \\
2.78(25.7)\end{array}$ & $\begin{array}{c}42.3(27.4) \\
54.2(24.8) \\
12.2(32.8)^{\star *}\end{array}$ & $\begin{array}{c}46.6(22.4) \\
59.2(20.6) \\
12.0(28.8)^{\star *}\end{array}$ & $\begin{array}{c}48.6(25.1) \\
57.9(20.2) \\
9.15(30.4)^{\star \star *}\end{array}$ & $\begin{array}{c}r_{s}=0.11 \\
0.019 \\
r_{s}=0.13 p=0.0065\end{array}$ & $\begin{array}{l}r=0.01 \\
0.85\end{array}$ \\
\hline $\begin{array}{l}\text { Angina } \\
\text { frequency }\end{array}$ & $\begin{array}{l}\text { Baseline } \\
\text { Follow-up } \\
\text { Change }\end{array}$ & $\begin{array}{l}58.8(26.6) \\
63.4(28.9) \\
6.14(20.4)^{\star}\end{array}$ & $\begin{array}{c}57.9(31.0) \\
67.1(29.2) \\
10.3(31.6)^{\star}\end{array}$ & $\begin{array}{c}67.7(26.4) \\
85.2(19.9) \\
17.4(23.3)^{\star \star \star}\end{array}$ & $\begin{array}{c}66.9(26.2) \\
89.7(16.4) \\
22.9(26.6)^{\star \star \star}\end{array}$ & $\begin{array}{c}r_{s}=0.11 \\
0.018 \\
r_{s}=0.36 p<0.0001\end{array}$ & $\begin{array}{l}r_{s}=0.21 \\
<0.0001\end{array}$ \\
\hline $\begin{array}{l}\text { Treatment } \\
\text { satisfaction }\end{array}$ & $\begin{array}{l}\text { Baseline } \\
\text { Follow-up } \\
\text { Change }\end{array}$ & $\begin{array}{c}70.8(20.7) \\
53.1(27.8) \\
-17.8(29.4)^{\star \star}\end{array}$ & $\begin{array}{c}73.1(15.2) \\
67.5(21.5) \\
-5.55(23.6)\end{array}$ & $\begin{array}{l}73.5(17.2) \\
78.6(16.1) \\
4.96(18.0)^{*}\end{array}$ & $\begin{array}{c}81.2(17.2) \\
88.2(15.0) \\
6.73(18.8)^{\star \star \star}\end{array}$ & $\begin{array}{c}r_{s}=0.25 \\
<0.0001 \\
r_{s}=0.50 p<0.0001\end{array}$ & $\begin{array}{l}r_{s}=0.27 \\
<0.0001\end{array}$ \\
\hline Quality of life & $\begin{array}{l}\text { Baseline } \\
\text { Follow-up } \\
\text { Change }\end{array}$ & $\begin{array}{l}43.1(20.3) \\
45.8(20.5) \\
3.97(24.9)\end{array}$ & $\begin{array}{c}38.9(19.5) \\
49.0(20.0) \\
10.4(22.4)^{\star \star \star}\end{array}$ & $\begin{array}{c}47.0(18.8) \\
63.9(21.8) \\
16.3(20.0)^{\star \star \star}\end{array}$ & $\begin{array}{c}46.1(19.2) \\
67.4(19.9) \\
21.6(22.0)^{\star \star \star}\end{array}$ & $\begin{array}{c}r_{s}=0.10 \\
0.027 \\
r_{s}=0.35 p<0.0001\end{array}$ & $\begin{array}{l}r_{s}=0.24 \\
<0.0001\end{array}$ \\
\hline
\end{tabular}

For comparison between baseline and follow-up Wilcoxon signed-rank tests were used and significance set at ${ }^{*}=p<0.05,{ }^{* *}=p<0.01$ and ${ }^{* \star *}=p<0.001$.

†For comparison between the four alternatives $r=S$ pearmen's rank correlation test were used for continuous variables.

$\mathrm{B}$, baseline; FU, follow-up. 
Table 6 Health related quality of evaluated life (HRQoL) by Short-Form 36 (SF-36) at baseline and follow-up in patients grouped according to their answer to the statement at follow-up that 'The expectations I had regarding my treatment have been met'

\begin{tabular}{|c|c|c|c|c|c|c|c|}
\hline & & $\begin{array}{l}\text { Completely } \\
\text { disagree } \\
\text { Baseline } \\
\mathrm{n}=48 \\
\text { Follow-up } \\
\mathrm{n}=44\end{array}$ & $\begin{array}{l}\text { Agree } \\
\text { partially } \\
\text { Baseline } \\
\mathrm{n}=79 \\
\text { Follow-up } \\
\mathrm{n}=76\end{array}$ & $\begin{array}{l}\text { Agree almost } \\
\text { entirely } \\
\text { Baseline } \\
\mathrm{n}=83 \\
\text { Follow-up } \\
\mathrm{n}=82\end{array}$ & $\begin{array}{l}\text { Agree entirely } \\
\text { Baseline } \\
\mathrm{n}=272 \\
\text { Follow-up } \\
\mathrm{n}=265\end{array}$ & $\begin{array}{l}\text { Correlation of } \\
\text { baseline values } \\
\text { between the } \\
\text { four alternatives } \\
\text { from completely } \\
\text { disagree to agree } \\
\text { entirely }\end{array}$ & $\begin{array}{l}\text { Correlation of } \\
\text { changes from } \\
\text { baseline to follow- } \\
\text { up between the four } \\
\text { alternatives from } \\
\text { completely disagree } \\
\text { to agree entirely\# }\end{array}$ \\
\hline & & Mean (SD) & Mean (SD) & Mean (SD) & Mean (SD) & $p$ value & $\begin{array}{l}\mathbf{r}_{\mathrm{s}} \\
\mathbf{p} \text { value }\end{array}$ \\
\hline PF & $\begin{array}{l}\text { Baseline } \\
\text { Follow-up } \\
\text { Change }\end{array}$ & $\begin{array}{l}50.1(25.7) \\
51.4(25.5) \\
0.000(10.7)\end{array}$ & $\begin{array}{l}51.7(21.4) \\
56.2(23.7) \\
3.73(18.2)\end{array}$ & $\begin{array}{l}63.0(23.6) \\
71.5(24.1) \\
8.75(19.8)^{\star \star \star}\end{array}$ & $\begin{array}{l}65.2(20.9) \\
77.0(19.9) \\
11.8(19.2)^{\text {***}}\end{array}$ & $\begin{array}{c}r_{s}=0.24 \\
<0.0001 \\
r_{s}=0.36 p<0.0001\end{array}$ & $\begin{array}{l}r_{s}=0.22 \\
<0.0001\end{array}$ \\
\hline $\mathrm{RP}$ & $\begin{array}{l}\text { Baseline } \\
\text { Follow-up } \\
\text { Change }\end{array}$ & $\begin{array}{l}27.3(35.7) \\
26.7(37.9) \\
0.610(32.4)\end{array}$ & $\begin{array}{l}24.7(35.2) \\
28.2(36.3) \\
4.51(40.8)\end{array}$ & $\begin{array}{l}43.4(40.6) \\
55.9(40.4) \\
11.8(37.1)^{\star \star}\end{array}$ & $\begin{array}{l}42.8(41.1) \\
64.2(40.7) \\
21.1(47.3)^{\star \star \star}\end{array}$ & $\begin{array}{c}r_{s}=0.15 \\
0.001 \\
r_{s}=0.34 p<0.0001\end{array}$ & $\begin{array}{l}r_{s}=0.18 \\
0.0001\end{array}$ \\
\hline $\mathrm{BP}$ & $\begin{array}{l}\text { Baseline } \\
\text { Follow-up } \\
\text { Change }\end{array}$ & $\begin{array}{l}45.3(25.1) \\
47.6(27.4) \\
0.825(20.6)\end{array}$ & $\begin{array}{l}46.5(19.9) \\
55.7(23.3) \\
9.21(26.2)^{\star \star}\end{array}$ & $\begin{array}{l}60.1(25.0) \\
68.4(25.9) \\
8.49(23.3)^{\star \star}\end{array}$ & $\begin{array}{l}58.7(25.1) \\
76.1(26.2) \\
16.9(28.0)^{\star \star \star}\end{array}$ & $\begin{array}{c}r_{s}=0.18 \\
0.0001 \\
r_{s}=0.36 p<0.0001\end{array}$ & $\begin{array}{l}r_{s}=0.19 \\
<0.0001\end{array}$ \\
\hline $\mathrm{GH}$ & $\begin{array}{l}\text { Baseline } \\
\text { Follow-up } \\
\text { Change }\end{array}$ & $\begin{array}{l}49.1(20.0) \\
43.8(17.5) \\
-4.30(13.6)\end{array}$ & $\begin{array}{l}49.5(18.4) \\
46.0(19.8) \\
-3.65(19.2)\end{array}$ & $\begin{array}{l}57.3(17.5) \\
57.9(20.5) \\
0.416(15.9)\end{array}$ & $\begin{array}{l}59.0(20.8) \\
68.0(22.0) \\
8.70(20.1)^{\star \star \star}\end{array}$ & $\begin{array}{c}r_{s}=0.20 \\
<0.0001 \\
r_{s}=0.42 p<0.0001\end{array}$ & $\begin{array}{l}r_{s}=0.28 \\
<0.0001\end{array}$ \\
\hline VT & $\begin{array}{l}\text { Baseline } \\
\text { Follow-up } \\
\text { Change }\end{array}$ & $\begin{array}{l}37.7(23.2) \\
41.6(21.3) \\
1.46(20.3)\end{array}$ & $\begin{array}{l}41.2(18.1) \\
43.7(19.3) \\
2.91(19.8)\end{array}$ & $\begin{array}{l}50.8(22.2) \\
56.5(21.5) \\
5.78(17.4)^{\star \star}\end{array}$ & $\begin{array}{l}50.5(23.7) \\
63.5(24.1) \\
12.8(23.9)^{\text {** }}\end{array}$ & $\begin{array}{c}r_{s}=0.17 \\
0.0003 \\
r_{s}=0.36 p<0.0001\end{array}$ & $\begin{array}{l}r_{s}=0.21 \\
<0.0001\end{array}$ \\
\hline SF & $\begin{array}{l}\text { Baseline } \\
\text { Follow-up } \\
\text { Change }\end{array}$ & $\begin{array}{l}65.0(29.7) \\
72.7(26.3) \\
5.95(22.5)\end{array}$ & $\begin{array}{l}64.7 \text { (26.2_) } \\
67.9(25.3) \\
1.86(26.1)\end{array}$ & $\begin{array}{l}72.5(23.3) \\
77.0(20.8) \\
4.81(20.1)\end{array}$ & $\begin{array}{l}76.5(23.2) \\
85.3(21.7) \\
8.78(24.4)^{\star \star \star}\end{array}$ & $\begin{array}{c}r_{s}=0.18 \\
0.0001 \\
r_{s}=0.30 p<0.0001\end{array}$ & $\begin{array}{c}r_{s}=0.10 \\
0.041\end{array}$ \\
\hline RE & $\begin{array}{l}\text { Baseline } \\
\text { Follow-up } \\
\text { Change }\end{array}$ & $\begin{array}{l}56.5(45.0) \\
53.6(45.8) \\
-2.96(44.9)\end{array}$ & $\begin{array}{l}54.7(42.1) \\
47.2(43.7) \\
-4.84(53.8)\end{array}$ & $\begin{array}{l}64.1(43.9) \\
68.3(38.8) \\
5.64(42.7)\end{array}$ & $\begin{array}{l}59.4(41.3) \\
75.2(37.8) \\
16.1(47.2)^{\star \star \star}\end{array}$ & $\begin{array}{c}r_{s}=0.02 \\
0.70 \\
r_{s}=0.25 p<0.0001\end{array}$ & $\begin{array}{l}r_{s}=0.18 \\
0.0001\end{array}$ \\
\hline $\mathrm{MH}$ & $\begin{array}{l}\text { Baseline } \\
\text { Follow-up } \\
\text { Change }\end{array}$ & $\begin{array}{l}64.2(23.7) \\
69.9(22.6) \\
2.44(16.8)\end{array}$ & $\begin{array}{l}65.2(19.6) \\
66.4(19.6) \\
1.18(17.0)\end{array}$ & $\begin{array}{l}70.1(18.0) \\
71.5(18.8) \\
1.28(15.8)\end{array}$ & $\begin{array}{l}71.8(19.4) \\
80.2(18.7) \\
8.19(18.3)^{\star \star \star}\end{array}$ & $\begin{array}{c}r_{\mathrm{s}}=0.13 \\
0.004 \\
r_{s}=0.29 p<0.0001\end{array}$ & $\begin{array}{l}r_{s}=0.19 \\
<0.0001\end{array}$ \\
\hline
\end{tabular}

For comparison between baseline and follow-up Wilcoxon signed-ranks test were used and significance set at ${ }^{*} p<0.05$, ${ }^{* *} p<0.01$ and ${ }^{* * *} \mathrm{p}<0.001$.

$\dagger$ For comparison between the four alternatives $r_{s=}$ Spearmen's rank correlation test were used for continuous variables.

$\mathrm{B}$, baseline; BP, bodily pain; FU, follow-up; GH, general health; MH, mental health; PF, physical function; RE, role emotional; RP, role physical; SF, social function.

The validity of the $\operatorname{ExpQ}$ was tested by comparing the compliance of the results with those of the HRQoL questionnaires included in the study. Overall, there was an improvement in HRQoL from baseline to follow-up. Furthermore, those who reported fulfilment of expectations, as well as improvements in HRQoL, had higher HRQoL measured by both the SAQ and the SF-36 at baseline than those who did not have their expectations fulfilled (tables 5 and 6).

Results from the patients' reported symptoms and the attitudes towards them at baseline and follow-up are presented in figure 3 .

\section{DISCUSSION}

The results of an earlier qualitative study in patients with suspected restenosis after earlier percutaneous coronary intervention (PCI) have raised questions regarding patients' needs, perceptions and expectations at the beginning of a healthcare process and to what extent these expectations were met at the end of the process. ${ }^{10}$ In order to try to measure patients' expectations and experiences in a standardised way we developed an instrument which was applied in this study. The study demonstrates that almost all the patients had high expectations in terms of information, treatment, which is in line with other studies that have measured expectations in patients in the same kind of healthcare systems. ${ }^{11}$ At the end of the care process, however, a significant proportion of our patients did not claim to have had their expectations fulfilled. There was also a strong correlation between the fulfilment of expectations and improvement in HRQoL. 


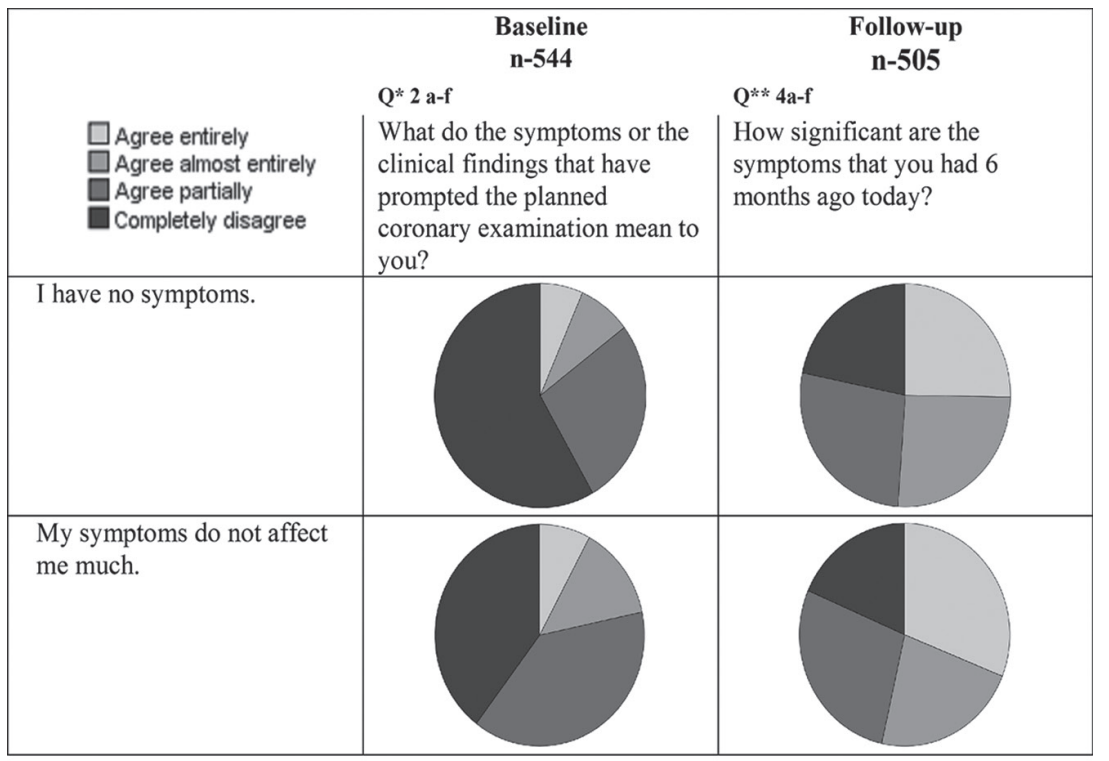

\begin{tabular}{|l|l|}
\hline $\begin{array}{l}\text { Completely disagree } \\
\text { Agree partially } \\
\text { Agree almost entirely } \\
\text { Agree entirely }\end{array}$ \\
$\begin{array}{l}\text { My symptoms are limiting my } \\
\text { ability to live an active life. }\end{array}$ \\
\hline $\begin{array}{l}\text { My symptoms are of a } \\
\text { physical nature. }\end{array}$
\end{tabular}

Figure 3 Results from the symptoms and the attitudes of patients.

Expectations have previously been evaluated in studies using qualitative methods covering issues such as understanding what the disease means, information to relatives and treatment perceptions. ${ }^{12}{ }^{13}$ Concerning CAD and revascularisation with CABG, a scaling instrument measuring expectations has been produced but is not widely used. ${ }^{14}$ For PREMs, questionnaires have been developed and validated but they have been designed to catch specific and general aspects of treatment, being taken care of and communication with doctors and nurses. ${ }^{15}$ Furthermore, they have not been developed especially to cover the entire chain of care and have not been specifically validated in coronary care patients.
At the follow-up, about one quarter of the patients still reported symptoms that greatly affected them and limited their living an active life. Additionally, a considerable proportion of the patients claimed to not be fully recovered. This was independent of the treatment that they had received, that is, whether they had undergone revascularisation or not. There was no clear correlation between persisting symptoms and HRQoL or fulfilment of expectations at follow-up, which is in contrast to other studies reporting a good correlation between treatment satisfaction or degree of symptoms as well as with HRQoL at follow-up after cardiac catheterisation or revascularisation. ${ }^{16}{ }^{17}$ One explanation for this could be that patients 
were included in the study before a diagnosis of CAD was firmly established and, as a consequence, $31 \%$ of the patients did not present with any significant coronary stenosis at the coronary angiography. Our previous qualitative study revealed that worries and conceptual issues may be important but the results of the present study indicate that symptoms and restrictions in daily life seem to be the most important issues from the patients' perspectives. The discrepancies might indicate a methodological differences as qualitative studies may identify not yet known or insufficient known phenomena, characteristics and meanings while quantitative studies examine how the given phenomena, characteristics and meanings are distributed in a population.

The present study provides important knowledge regarding patient involvement in decision-making of their treatment. Thus, a majority of all patients in this study wanted to participate in decision-making regarding their treatment. ${ }^{1}$ This attitude may well have changed over time since Deber et al reported in 1996 that most patients wanted the doctor to make all the decisions, while in a later study presented in 2007, a majority of the patients wanted to actively take part in the decision-making process regarding their treatment. ${ }^{18} 19$

We also asked about the perception of different treatment alternatives. There was, in general, a positive attitude towards life style changes and also to longterm medical prophylactic treatment, although a clear majority of the patients entered the chain of care with the perception or expectation that this would involve a PCI. The strong preponderance that was found in the present study for revascularisation in general, and PCI in particular, may be a result of either information shared by healthcare personnel in previous stages of the healthcare process or a perception among patients that revascularisation could offer the chance of a definite cure compared with other treatment modalities. The fulfilment of expectations, however, did not seem to differ regarding the actual revascularisation procedure that was performed or not.

\section{LIMITATIONS}

There are a number of issues that must be kept in mind when interpreting our results. First, it must be recognised that the study was performed in a specific healthcare system, that is, the Swedish, where almost all specialised cardiac care is publicly organised, financed and provided for. Second, the study comprised an unselected patient population with different phenotypes and in which obviously not all the patients actually suffered from significant CAD. No significant coronary stenosis was observed in $31.7 \%$ of the patients and thus their symptoms are likely explained by reasons other than angina pectoris. Further studies focusing on defined, targeted patients may reveal more relevant information of value for designing healthcare processes in CAD patients as well as other patient categories. Furthermore, although the results of the expectation questionnaire correlated with established HRQoL questionnaires, it does need further validation and testing, including test-retest evaluations, in a larger population before it can be more widely used as a patient-reported experiences instrument. ${ }^{14}$

Finally, the ExpQ were produced, tested and validated in the Swedish language only and further use in other languages must be preceded by double translation, reliability tests and a validation process in the actual language in which it is supposed to be used.

\section{CONCLUSIONS}

Patients with suspected $\mathrm{CAD}$ had high confidence in the healthcare system and high expectations regarding receiving proper care at the start of a healthcare. They had, in general, a positive attitude towards the chain of care, which is in line with current recommendations from the guidelines for $\mathrm{CAD}$, and a positive attitude regarding their involvement in the decision-making for their care process. At the end of the care process, however, only $56.4 \%$ of the patients claimed to have had their expectations fulfilled. Fulfilment of expectations correlated with patient-reported outcome measures using established HRQoL instruments. Measuring fulfilment of expectations at the end of a healthcare process may, therefore, be used as a meaningful PREM to evaluate the results of a chain of care for suspected CAD

\section{Author affiliations}

${ }^{1}$ Department of Cardiology, The Medicine Institute of Sahlgrenska Academy, Gothenburg, Sweden

${ }^{2}$ Faculty of Caring Science, University of Borås, Borås, Sweden

${ }^{3}$ Multidisciplinary Pain Center, Sahlgrenska University Hospital and Institute of Medicine, Gothenburg, Sweden

${ }^{4}$ Department of Medicine, Norra Ivsborg County Hospital, Trollhttan, Sweden

${ }^{5}$ Department of Medicine, Skaraborg Hospital, Skövde, Sweden

${ }^{6}$ Department of Medicine, Sothern Älvsborg Hospital, Borås, Sweden

Acknowledgements The study was supported by grants from The Health and Medical Care Committee of the Regional Executive Board, Region Västra Götaland, and from the Swedish state. We acknowledge the statistical advice given by Suzy Caraza, Mattias Molin and Nils-Gunnar Perhsson.

Contributors All the participated authors have contributed and approved of the manuscript.

Competing interests None Declared.

Ethics approval Regional Ethical Review Board at Gothenburg University (DNR: 667-10)

Provenance and peer review Not commissioned; externally peer reviewed.

Open Access This is an Open Access article distributed in accordance with the Creative Commons Attribution Non Commercial (CC BY-NC 4.0) license, which permits others to distribute, remix, adapt, build upon this work non-commercially, and license their derivative works on different terms, provided the original work is properly cited and the use is non-commercial. See: http://creativecommons.org/ licenses/by-nc/4.0

(c) Article author(s) (or their employer(s) unless otherwise stated in the text of the article) 2017. All rights reserved. No commercial use is permitted unless otherwise expressly granted.

\section{REFERENCES}

1. NICE clinical guideline 126. management of stable angina. 2012. http://wwwguidanceniceorguk/cg126. 
2. Montalescot G, Sechtem U, Achenbach S, et al. Task Force Members ESC Committee for Practice GuidelinesDocument Reviewers. 2013 ESC guidelines on the management of stable coronary artery disease: the task force on the management of stable coronary artery disease of the European society of cardiology. Eur Heart J 2013;34:2949-3003.

3. Porter ME OTE, . How physicians can change the future of health care. JAMA 2007;297:1103-11.

4. Hess EP, Knoedler MA, Shah ND, et al. The chest pain choice decision aid: a randomized trial. Circ Cardiovasc Qual Outcomes 2012;5:251-9.

5 Anker SD, Agewall S, Borggrefe M, et al. The importance of patientreported outcomes: a call for their comprehensive integration in cardiovascular clinical trials. Eur Heart J 2014;35:2001-9.

6. Mackintosh A, Gibbons E, Casañas i Comabella C, et al. A Sructured Review of Patient-Reported Outcome Measures used in Elective Procedures for Coronary Revascularisation. Patientreported Outcome Measurement Group Department of Public Health University of Oxford . 2010

7. Jenkinson C, Coulter A, Bruster S, et al. Patients' experiences and satisfaction with health care: results of a questionnaire study of specific aspects of care. Qual Saf Health Care 2002;11:335-9.

8. Dempster M, Donnelly M. Measuring the health related quality of life of people with ischaemic heart disease. Heart 2000;83:641-4.

9. Spertus JA, Winder JA, Dewhurst TA, et al. Development and evaluation of the seattle angina questionnaire: a new functional status measure for coronary artery disease. J Am Coll Cardiol 1995;25:333-41.

10. Odell A, Grip L, Hallberg LR. Restenosis after percutaneous coronary intervention (PCl): experiences from the patients' perspective. Eur $J$ Cardiovasc Nurs 2006;5:150-7.
11. Nilsdotter AK, Toksvig-Larsen S, Roos EM. Knee arthroplasty: are patients' expectations fulfilled? A prospective study of pain and function in 102 patients with 5-year follow-up. Acta Orthop 2009;80:55-61.

12. Barut VF K, Mead A. What do angina patients understand of options for myocardial revascularisation Br J Cardiol 2012;19:65-9.

13. Lukkarinen $\mathrm{H}$. Life course of people with coronary artery disease. $J$ Clin Nurs 1999;8:701-11.

14. Barnason S, Zimmerman L, Atwood J, et al. Development of a selfefficacy instrument for coronary artery bypass graft patients. J Nurs Meas 2002;10:123-33.

15. Jenkinson C, Coulter A, Bruster S. The picker patient experience questionnaire: development and validation using data from in-patient surveys in five countries. Int J Qual Health Care 2002;14:353-8.

16. Spertus JA, Salisbury AC, Jones PG, et al. Predictors of qualityof-life benefit after percutaneous coronary intervention. Circulation 2004;110:3789-94.

17. Ulvik B, Wentzel-Larsen T, Hanestad BR, et al. Relationship between provider-based measures of physical function and self-reported health-related quality of life in patients admitted for elective coronary angiography. Heart Lung 2006;35:90-100.

18. Deber RB, Kraetschmer N, Irvine J. What role do patients wish to play in treatment decision making? Arch Intern Med 1996;156:1414-20.

19. Deber RB, Kraetschmer N, Urowitz S, et al. Do people want to be autonomous patients? preferred roles in treatment decision-making in several patient populations. Health Expect $2007 ; 10: 248-58$ 